\section{Stort og godt om medisinsk genetikk}

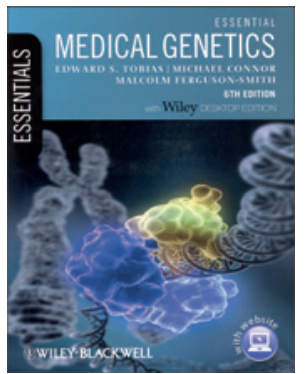

Edward S. Tobias, Michael Connor,

Malcolm Ferguson-Smith

Essential medical genetics

6. utg. 344 s, tab, ill. Chichester: Wiley-

Blackwell, 2011. Pris GBP 35

ISBN 978-1-4051-6974-5

Dette er sjette utgave av en lærebok i medisinsk genetikk som, ifølge forlaget, er særlig beregnet for leger i spesialisering i medisinsk genetikk. Boken er inndelt i tre deler: basale prinsipper, klinisk genetikk samt en oversikt over og veiledning i bruk av nyttige databaser. Hver del er igjen inndelt i oversiktlige kapitler. En digital interaktiv versjon med linker til aktuelle databaser følger med.

Denne utgivelsen fremstår som en av flere omfattende, godt oppdaterte og pedagogiske lærebøker i medisinsk genetikk. Formatet er leservennlig, og det er rikelig med gode illustrasjoner i farger. Hvert kapittel har en nyttig oppsummering med henvisning til videre lesning og flervalgsspørsmål (med fasit) for selvevaluering. Det er lett å finne frem. I et fag som er i så rask utvikling som medisinsk genetikk, vil det alltid være et behov for å oppdatere seg på Internett. Jeg vil derfor særlig fremheve den tredje delen, hvor man blir instruert $\mathrm{i}$ hvordan man skal finne frem i de mange databasene som nå eksisterer. Dette vises ved hjelp av eksempler, både i klinisk diagnostikk og i laboratoriediagnostikk.

Jeg kan trygt anbefale boken til leger som vil investere mye tid på å sette seg inn i grunnleggende prinsipper i medisinsk genetikk. For de fleste leger i andre spesialiteter enn medisinsk genetikk vil det imidlertid være andre, mindre omfattende og mer klinisk orienterte bøker som er bedre egnet som en innføring eller oppdatering innen medisinsk genetikk. Et eksempel på en slik bok er den nedenfor omtalte Practical genetic counselling.

\section{Karen Helene Ørstavik}

Avdeling for medisinsk genetikk

Seksjon for klinisk genetikk

Oslo universitetssykehus, Rikshospitalet

\section{Lite og godt om medisinsk genetikk}

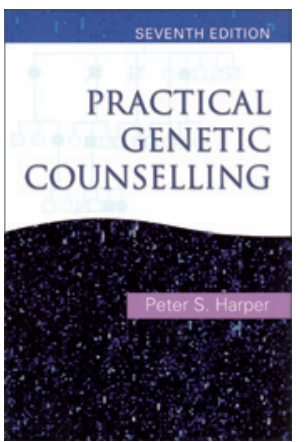

\author{
Peter S. Harper \\ Practical genetic counselling
}

7. utg. 407 s. tab, ill. London: Hodden Arnold 2010. Pris GBP 40

ISBN 978-0-340-99069-8

Dette er sjuende og sannsynligvis siste utgave av en bok som flere generasjoner genetikere har hatt glede av. Forfatteren har arbeidet i medisinsk genetikk i mer enn 40 år, og første utgave kom allerede i 1981. Mye har skjedd innen medisinsk genetikk på disse 30 årene, men som forfatteren selv nevner i forordet, er det også mye som er uforandret. De spørsmålene og problemstillingene som familiene kommer med, er stort sett de samme. Og genetisk veiledning dreier seg nettopp om arbeid med familier.

De tre delene har i alt 28 kapitler. Første del omhandler generelle aspekter ved genetisk veiledning, andre del dreier seg om genetisk veiledning ved sykdommer og misdannelser i de enkelte organsystemene, mens man i tredje del tar for seg genetisk veiledning $i$ et bredere perspektiv, bl.a. dagens aktuelle problemstillinger om screening for genetiske sykdommer.

Det er ingen andre illustrasjoner enn skjematiske stamtavler, men en rekke nyttige tabeller, bl.a. over gjentakelsesrisiko ved mange hyppige tilstander. Boken er derfor godt egnet som et oppslagsverk. I de fleste tilfeller vil det være nødvendig med supplerende informasjon, og forfatteren henviser til en rekke nyttige nettsteder. Den er godt oppdatert på nye teknikker innen prenatal diagnostikk, slik som preimplantasjongenetisk diagnostikk og diagnostikk av føtalt DNA i mors blod. Forfatteren påpeker hvor viktig det er at genetisk veiledning er en integrert del av disse nye metodene.

I forordet nevner forfatteren at han opprinnelig skrev denne boken for de som ikke var eksperter eller spesialister, og at han ble forbauset over å finne at den også brukes av dem som arbeider innen fagfeltet medisinsk genetikk. Dette er også min erfaring. Å «slå opp i Harper» er ofte en god begynnelse når man skal sette seg inn $i$ en medisinskgenetisk problemstilling.

I et hendig og beskjedent format står det her litt om det meste, klokt formulert og godt formidlet av en meget erfaren medisinsk genetiker. Boken vil være nyttig for leger i en rekke andre spesialiteter enn medisinsk genetikk, særlig innen pediatri, gynekologi og nevrologi.

Det er med glede jeg kan anbefale denne oppdaterte utgaven til alle leger som er interessert i medisinsk genetikk og genetisk veiledning.

Karen Helene Ørstavik

Avdeling for medisinsk genetikk

Seksjon for klinisk genetikk

Oslo universitetssykehus, Rikshospitalet 